\title{
The Care of Institutionalized Elderly: Principles for Action of Multidisciplinary Team
}

\section{Soares $E^{*}$}

Universidade Estadual Paulista Julio de Mesquita Filho Marilia, São Paulo, Brazil

*Corresponding author: Soares E, Universidade Estadual Paulista Julio de Mesquita Filho Marília, São Paulo, Brazil, Tel: 55 14996343665; E-mail: edsoares@marilia.unesp.br

Rec date: Oct 06, 2014; Acc date: Dec 22, 2014; Pub date: Dec 24, 2014

Copyright: (C) 2014 Soares E. This is an open-access article distributed under the terms of the Creative Commons Attribution License, which permits unrestricted use, distribution, and reproduction in any medium, provided the original author and source are credited.

\begin{abstract}
The increase in the elderly population, in spite of being a conquest, carries with it a series of personal, social and economical consequences. Aging is a natural process that involves a series of losses, among which we can mention the decrease in the ability to withstand the overloads of the environment and not necessarily a synonym for disease. The elderly, with greater or lesser degree of impairment is an individual who needs special care. Such necessity is often supplied by a member of the family, or by professionals hired for this purpose. But, not rarely, a greater demand for care leads the subject to hospitalization in residential institutions for long-term care facilities for the elderly (LTCFe's). In this perspective, this article of opinion aims discuss and present, from the experience in the development of projects with the elderly population, issues relating to 'act of caring', with particular reference to the institutionalized elderly.
\end{abstract}

Keywords: Human Aging; Elderly caregivers; Institutionalization

\section{Introduction}

This manuscript is the result of work experience with institutionalized elderly in Brazil. The main focus is on practical instructions for multidisciplinary work with elderly and institutionalized.

The increase in the elderly population is the result of several factors. Amongst the main factors, we can point the determinants social, economic, personal, behavioral, environmental, cultural, etc. [1]. However, according to Couto, although the increase in longevity represents a conquest for the population and for science, still prevails socially the idea that aging is something to be avoided. In a context in which the cult of youth is increasingly strengthened, old age is permeated by stereotypes and prejudices which reduce it to a phase of decline and loss [2]. According to Colom and Zaro, the stereotypes, in general, grant to old age a negative reality [3]. The social consensus accepts as inevitable facts loss of mental capacities, memory loss, vulnerable health, constant suffering from diseases or claims for attention. These losses/characteristics seem to justify a stereotyped behavior associated with terms such as "finished", "useless", "sick", "incapable", "unproductive", "dependent" and "social burden", leading the person to rejection and social marginalization.

On this negative perspective, Santana, and Sena point to the fact that the aging process is classified into three aspects: biological, psychological and social [4]. The first is presented the change that has occurred in the body of the individual, such as wrinkles, hair whitening, reduced height, sensory changes, among others. In the second are placed the fear of death, of loneliness, how to deal with the biological and social losses. In the social plan is about to the rejection of the work field and, even, at relations with others.

It is not that decline and losses do not occur. The problem occurs when we reduce the process of aging in these terms, and more severe, when we do not conceive that the process of aging is a natural process that is part of human development and, worse still, when we conceive that, during this process the individual is no more likely to change. In that sense, we must consider, as Beauvoir to say that the "old age is not a static fact; it is the result and the extension of a process" (p.17) [5].

\section{The institutionalized elderly}

The institutionalisation can be regarded as a modality of experience denominated by Martins of "event", in which radical changes occur and, in all senses, in the life of the elderly [6]. According to Houaiss \& Villar, institutionalizing means among other things, officiate; ingrain [7]. We can say, without being pretense of discussing or deepen the foucaltian's analysis or Goffman's, that the Residential institutions for Long-Term Care Facilities for the Elderly (LTCFe's) are, even 'unconsciously', spaces of individual and social control, where persist power relations; hierarchical spaces, where the subject must undergo, even giving up their individuality [8-10].

In accordance with Pavarini, when the family decides by institutionalization of elderly, generally it is based on one or more of the three meanings given to asylums: asylum-insulation (resulting from the design given by common sense as 'elder abandon depot' ); asylum-health (mainly for elderly people of low income, that they associate with the hospital, which possibly would have better medical assistance); and the asylum-refuge (confused as a place where the elderly can have an own space, safeguarding his power of decision) [11].

For many authors the asylums are generally seen as a 'path of no return', regarding both the family and the community if he forgets the elderly 'inpatients'. These elderly people, by its turn, not infrequently, end up eventually losing their identity and citizenship, which can lead to loss of autonomy. This occurs in a consequence of conducts and behaviors governed by the rules of asylums $[12,13]$. 
The elderly's institutionalization adaptation is extremely difficult. Zimerman observes that, the difficulties encountered by the elderly in relation to the process of institutionalization have connection, for example, the changes of parameters [13]. I.e., for example, the elderly lives with strange people and in a strange place. To these factors we can still add the losses (freedom, privacy, coexistence with family/ friends, etc.), the lack of peaceful coexistence with the opposite sex and abandonment or feeling of abandonment, by friends and family.

This reality is worsen, not rarely, by reduction or even loss of functional capacity, in terms of realization of activities of daily living; loss or decrease of cognitive abilities such as memory, learning, judgment and by social interaction and motivation reduced, among others. Tomasini \& Alves highlights how losses arising from institutionalization the loss of identity and autonomy and the generational segregation [14].

According to Farias, Guimarães \& Simas the LTCFe's feature own aspects and determine, through existing institutional norms and practices derived from historically institutionalized customs, conducts and behaviors [12]. In the majority of these institutions, activities are carried out in the same environment and under a single authority; routine is practically equal for all. Individual differences are ignored, as well as the history of life of each one. In this context, the elderly will lose their identity and their autonomy; becoming a liable being living in a strange environment. Such factors typically lead the institutionalized individuals to a greater or lesser degree of depression and/or anxiety [15,16]. According to Parmelee, Katz and Lawton [17].

The institutionalization for the great majority of older people is a source of pain and sorrow, the environment becomes silent, indifferent, empty, going to represent the final moments of his life and may contribute to the greater psychological problem of the elderly: depression (p.69).

It is important to point out that depression is associated with increased risk of morbidity and mortality, with increase in use of health services, to negligence in self-care, reduced adherence to treatment regimens and greater risk of suicide [15,18-20]. Depressive episodes, associated with other pathologies installed postinstitutionalization or even pre-existing and often aggravated by the process of institutionalization, can precipitate the installation of cognitive decline and/or dementia. According to the criteria of DSMIV (Diagnostic and Statistical Manual of Mental Disorders), dementia can be defined as a syndrome characterized memory decline associated with deficit of at least one other cognitive function (language, agnosia, praxis or executive functions) with enough intensity to interfere in social or professional performance [19]. Per memory we understand the process by which, previous experiences lead to alteration of behavior [21]. Therefore, the diagnosis of dementia requires the occurrence of memory impairment, although this function can be relatively preserved in the early stages of some forms of dementia. Initially can be observed decline in recent memory. Such situation may progress to long-term memory (already consolidated ones) decline, especially of autobiographical memory, i.e., the history of the individual; of personal parameters constructed over the course of his life. The elderly, in this context of memory decline, loses dramatically what confers his subjective identity. Squire \& Kandel reinforce this idea by stating that "memory loss leads to loss of the sense of self, the loss of our history of life and the loss of lasting interactions with other human beings" (p.10) [22]. Izquierdo also reinforces this idea when he says that: "the entirety of memories each one of us has is what characterizes us as individuals" (p.13) [23].
In relation to the prevalence of dementia and depression, Reys and collaborators stress that:

Dementia and depression are the most common psychiatric disorders in elderly. Dementia affects approximately $5 \%$ of the elderly at 65 years of age, and approximately $20 \%$ of those with 80 years or more. Recent study showed that, in Brazil, the incidence of dementia in the elderly residents in the community achieves a rate of 13,8 per 1000 inhabitants/year, for Alzheimer's Disease (AD) the index is 7.79. Depression also have prevalence rates between $5 \%$ and $35 \%$, varying according to the level of severity. The prevalence of depressive symptoms in the population above 65 years of age living in the community varies between $10,3 \%$ and $13,5 \%$ and Brazil reaches $14,3 \%$ (p.401) [24].

It is important to highlight that the aging should be understood as a natural process of physiological wear of body systems. Such wear can cause reduction of physical capacities, relative increase of inability to carry out daily activities, morphological, biochemical, and psychological changes, loss of social roles, solitude, affective losses, and increased vulnerability, decreased ability of recovering from the effects of events which disturb the body (resilience), smaller neural plasticity/ behavioral 16. The process pace and the impact on quality of life depends on economical, genetic, demographical, behavioral, and socio-cultural factors. Institutionalization can be a factor of negative impact on the elderly health and, allied to it, the excessive consumption of medicines.

The framework outlined until now just demonstrates the complexity of strategies elaboration to care for institutionalized elderly and points to the need to not only know the aspects involved in the institutionalization process, but the interaction between them. The majority of LTCFe's, in spite of ignoring such aspects, engages to meet the basic needs of housing, feeding, health, and social harmony, namely, a better quality of life. But, even this basic commitment is not always met in a satisfactory manner, as indicated by some studies [25-28]. Regarding the care provided in such institutions, it is observed that many times they seems inadequate, inefficient and even non-existent, when the caregivers are unprepared or overloaded [29]. However, in spite of many authors consider institutions as asylums inappropriate locations, we must consider that, in the absence of these locations, many elderly would be living on the street or being poorly attended by relatives [16].

Despite the negative aspects of institutionalization, Soares, Coelho and Carvalho indicates that changes in the physical and political environment of these institutions may bring benefits in relation to the elderly adaptive process [16]. In this respect, it is important to note that some LTCFe's have passed through expressive modifications [15]. Amongst such changes, we can highlight the concern with the improvement of physical space and management system; awareness about the need for recruitment of professionals specialized in several areas, in order to form multidisciplinary team; awareness of need for training of its employees and the concern to promote activities that contributes to improvement of health conditions of elderly. Thereby, seeing the possibility of collaborating for LTCFe's implement activities in favor of improvement of elderly living conditions was proposed the implementation, by the Laboratory of Cognitive NeurosciencesLaNeC-Universidade Estadual Paulista-Unesp, of the extension and research project Memory and Aging: Cognitive Rehabilitation in two LTCFe's located in the town of Marilia SP. The project, aims, in general lines, 1) Identify and monitor risk factors related to cognitive decline and the mood disorders (anxiety and depression) in 
individuals residing in LTCFe's; 2) promote activities focused on maintenance of cognitive functions and cognitive rehabilitation; 3) empower professionals from diverse areas for action, in terms of prevention, and 4) empower and provide psychological support to employees/caregivers of LTCFe's answered. In relation to the latter objective it is worth noting that, in this context, most of the times, the caregivers who work in LTCFe's are the only support (physical and emotional) and the only contact with the outside world that the institutionalized elderly finds, hence the importance not only of technical training, but the psychological-affective preparation to act with the aforementioned population.

\section{The caring}

Elderly Caregiver can be defined in general terms as the individual skilled to assist the elderly who presents limitations to perform activities of daily living, making connection between the elderly, family, institution and health services. According to the Practical Guide of the Caregiver from Ministry of Health [30].

Caring means attention, precaution, caution, dedication, affection, burden and responsibility. Take Care is serve, is offer to other, in the form of service, the result of your talents, preparation and choices; is to practice the care. Care is also perceive the other person as it is, and how it shows, their gestures and speeches, his pain and limitation. Realizing this, the caregiver has conditions to provide care in an individualized manner, from their ideas, knowledge and creativity, taking into consideration the special features and needs of the person to be cared. This care must go beyond the care with the physical body, since in addition to the physical suffering resulting from a disease or limitation, must be taken into account the emotional matters, the history of life, the feelings and emotions of the person to be cared (p. 9).

In this respect, it can be said that the caregiver is not a simple technically trained professional or someone who provides a service like any other. The caregiver should have some own characteristics, such as: a) respect for the elderly; i.e., considering that he is an unique being; that has a history; needs; desires; feelings; b) patience and tolerance, i.e., be aware that elderly are more slow, hear less, 'think more' and, many times, present behaviors, considered by caregivers and/or family members, such as childish, and oftentimes, mood disorders, such as depression, anxiety or even drastic changes of humor; c) constant search for information (knowledge) about the elderly; d) constant search of integration with the elderly; personification of care; e) take pleasure in working with older people; e) emotional balance; f) value team work; g) possess basic knowledge of hygiene, health and psychology of the elderly; h) have basic notion about various diseases that affect older people, and; i) initiative.

The Practical Guide of the Caregiver of the Ministry of Health also clarifies that the "occupation of caregiver integrates the Brazilian Classification of Occupations - CBO under the code 5162" [30]. As the $\mathrm{CBO}-5162$, the caregiver is defined by someone who "cares from goals established by specialized institutions or direct responsibles, while ensuring the well-being, health, nutrition, personal hygiene, education, culture, recreation and leisure activities of the person assisted" (p. 10). Thus, we can say that caregiver is, the person, from family or community, which provides care to another person of any age, who is in need of nursing care. Such individual may or may not be remunerated.
We also consider that individuals who perform activities with the elderly, such as for example, in extension projects, internships and activities of scientific research, are nonetheless caregivers. From this consideration, the $\mathrm{LaNeC}$ defined some fundamental principles to be observed during the execution of programed activities with the elderly in LTCFe's where the project Memory and Human Aging: Cognitive Rehabilitation is developed:

- The practical activities, group or individual, carried out among the elderly should not constitute a simple application of therapeutic processes in the strict sense of the term. Such activities are also, and mainly, the occasion of conviviality with 'another human being'.

- The activities developed in extension projects or research or training courses aims at specific aspects of subject-target of activity. However, cannot be ignored the fact that if it acts with people who cannot be reduced to the specific aspect of actuation. i.e., we operate with multiple dimensions, which are not isolated. Thus, for example, we cannot simply isolate the cognitive dimension (memory, language, learning, etc.) of the emotion, the physical conditions in terms of general health, of functional abilities, in the sense of ability to perform activities of daily living, etc.

- The activities with older populations should be applied from the understanding and acceptance of the principle that plasticity (neural and behavioral) is not restricted to the early stages of development, but that, even in a different manner, lasts for the entire life cycle. This principle is fundamental not only for the preparation of the activities, as also for the evaluation of results.

- The respect for individuality, for desire of the elder is an essential principle. This respect necessarily implies in knowledge about the reality of the subject in sense lato. Without such knowledge is, for example, impossible to motivate, establish relations of cause and effect and, mainly, to transcend a unilateral relationship in which the 'caregiver' simply establishes rules and procedures, i.e. 'indicates the path to' and not 'walks along to'.

- The practical activities/therapies with the elderly should take into account that the body works as a whole in dynamic relationship with the environment [31]. Also Simone De Beauvoir conceives the human being as a whole, so when characterized it as old, it is important to pay attention to the physical aspects, social, psychological [5]. For Bueno the reactions provoked by the stimuli are determined not by physical features of the situation, but by biological laws of behavior, to propose that, for the body, the stimulus does not reduce to externally defined physical characteristics [32].

- The non-infantilization of elderly is a basic fundament. When the elderly person is treated as a 'child', mainly through words, such as "cutie", "beautie", "poor soul", "so cutie", etc., or actions, in the sense of paternalistic behaviors that offend the autonomy of the subject; there is an impact in terms of self-esteem, i.e. normally the elderly have their self-esteem decreased and/or assimilate the 'labels' and behave in accordance with it. In this sense, it is important to note that, behaving according to the labels' can be related to the context of hidden power established between caregiver and the cared individual. As the cared individual is, in a certain way in a situation of 'disadvantage' in relation to the caregiver, it establishes a behavioral dynamic in which, even contrary to his will, he tries to meet the expectations of the caregiver. 
- The elder cared should be treated with education and urbanity. Must be treated like our 'friend' or as our 'older neighbor', with whom we talk with a certain constancy and, with which we do not maintain a relationship of dominance.

- One of the ways to improve the self-esteem of the elderly is to make him feel useful. In this sense, to the possible extent, during the execution of activities close to the elderly and respectful with the limitations of these; for example, asking for help, opinion.

- Try to break the silence. Most of the times, the elderly, especially the institutionalized elderly, are immersed in their world, given by Ricoeur the title about the "solitary speech or dialog with himself" (p. 26-27) [33]. Normally, after being encouraged to speak, they tend to refer to distant past (autobiographical memories) or somatic complaints. In this sense we must give space to the expression of the elderly, but always looking for not reinforce negative thoughts and feelings. It should be noted that, on some occasions the elderly presents a difficulty to express themselves, especially if they show any sensory or cognitive deficit. Meanwhile, Berger observes that [34]:

A person isolated for a very long time may become apathetic and have difficulty in establishing interpersonal relationships and respond to questions, or express a great volubility in such a way that it becomes difficult to establish a logic conversation (p. 404).

Therefore, stimulation for expression is fundamental, and is, step by step, when you can establish a dialogical situation with the elderly. Remembering that the 'expression' 'breaking the silence' is not confined to the world of words. It is the expression of the whole body and the organism with its environment. The individual who works with the elderly should, therefore, develop sensitivity to 'read' another's expression.

- Another basic principle is: 'Listen more than talk. It is important to stimulate the expression and, not only show interest on what the elderly expressed, but really 'be interested' in the expression of the other. It is important to note that the elderly person feels the need to express themselves, and many times their right of expression is revoked in a subtle or even violent way. Value the experience of the elderly is make him feel important, useful. In this sense, Foucault points to the importance of adopting the silence and not interrupt anyone who speaks [35]. Be careful to assimilate what is spoken and avoid physical attitudes, such as agitation, not to interfere in listening.

- Liability in relation to affective involvement is of extreme importance, especially when it comes to institutionalized elderly. In most of times the subject is institutionalized in a situation of affective shortage and, in such a situation, usually cling with extreme ease the caregiver, and can even create a bond of affective dependence [36]. For this reason, in the event of the development of research projects or extension ones, in order to avoid suffering (feeling of loss/abandonment) when there is no change of members in projects; it is desirable that we proceed regularly, during the execution of projects, exchanges between the members that operate along the elderly group. I.e. at the same time that makes necessary the establishment of a close relationship to the elderly, there should be no "exclusivity" in these relations. You should also take care with the posture of "segregation". Especially in extension projects or internships, not elect a "preferred elderly". All are entitled to the same care and attention.

- Avoid issue, especially in conversation with the elderly, opinions about the institution, therapies, employees and caregivers.
- The actuation on the project assumes technical responsibility, which can be translated as preparation, which leads to theoretical and practical skills. The technical responsibility presupposes, in addition to the constant reading on the topic, respect the schedules, timelines and programs.

- Take care that there is no dominance among the subjects treated, especially during the development of group activities.

\section{Conclusion}

The increase in the elderly population, in spite of being a conquest, carries with it a series of personal, social and economical consequences. Aging is a natural process and not necessarily a synonym for disease. However, no one can deny that, with the natural wear of the body, this becomes more vulnerable and less resilient. This process is often combined with the psychological suffering in function of personal, economic, and social loss, and the reduction of the subject's autonomy. Thus, the elderly with greater or lesser degree of physical, mental, and/or psychological impairment needs support. In some cases, the support is given at the very heart of the family and, in others, by LTCFe's, which is not the ideal, but in many cases, it is the only outlet for the elderly has the minimum support. In both cases, as previously stated, the figure of the caregiver is essential. As caregiver we can also understand all the individuals who work or perform tasks upon application of therapeutic processes, research or extension projects. However such individual must have certain technical, social and psychological skills, which can be summarized as 'being compromised with the cared subject'. The commitment presupposes a close relationship. However, the relationship between caregiver and cared may not be a relationship of dependence in order of power relations. Quite the contrary, it must be a relationship of complicity, in which the 'caregiver also feels cared by individual who, he cares'.

\section{References}

1. World Health Organization (WHO) (2005) Envelhecimento ativo: uma política de saúde. Brasília, Organização Pan-Americana de Saúde.

2. Couto MCPP et al. (2006) Resiliência no envelhecimento: risco e proteção. In: Falcão DVS et al. Maturidade e velhice: pesquisa e intervenções psicológicas. São Paulo, Casa do Psicólogo: 315-38.

3. Colom, R, Zaro, MJ (2007) A psicologia das diferenças. São Paulo, Vetor.

4. Santana HB, Sena KL (2002) Repensando a 3 idade: um novo olhar sobre o envelhecer. Recife, UFPE.

5. Beauvoir S (1990) A velhice. (3ste dn) ed. Rio de Janeiro, Nova Fronteira.

6. Martins JG (2007) Experiência e subjetividade em Claude Romano. In: Cantista MJ. Desenvolvimento da fenomenologia na contemporaneidade. Porto, Campo das Letras: 167-214.

7. Houaiss A, Villar MS (2001) Dicionário Houaiss da língua portuguesa. Rio de Janeiro, Objetiva.

8. Foucault M (1990) Microfísica do poder. (9 ste dn). Rio de Janeiro, Graal.

9. Foucault M (1998) O nascimento da clínica. (5 ste dn). Rio de Janeiro, Forense Universitária.

10. Goffman E (1996) Manicômios, prisões e conventos. São Paulo, Perspectiva.

11. Pavarini SCI (1996) Dependência comportamental na velhice: uma análise do cuidado prestado ao idoso institucionalizado. [tese]. Universidade Estadual de Campinas, Campinas.

12. Farias SF, Guimarães ACA, Simas JPN (2005) O ambiente asilar e a qualidade de vida nos idosos. A Terceira Idade 16: 54-71.

13. Zimerman GI (2000) Velhice: aspectos biopsicossociais. Porto Alegre, Artmed. 
Citation: Soares E (2014) The Care of Institutionalized Elderly: Principles for Action of Multidisciplinary Team. J Gerontol Geriatr Res 3: 1000191. doi:10.4172/2167-7182.1000191

Page 5 of 5

14. Tomasini SLV, Alves S (2007) Envelhecimento bem sucedido e o ambiente das instituições de longa permanência. RBCEH 4: 88-102.

15. Soares E (2010) Projeto Memória e Envelhecimento: capacitando profissionais e aprimorando aspectos cognitivos em idosos institucionalizados. RBCEH 7: 62-73.

16. Soares E, Coelho MO, Carvalho SMR (2012) Capacidade funcional, declínio cognitivo e depressão em idosos institucionalizados: possibilidade de relações e correlações. Rev Kairós Gerontologia 15: 117-39.

17. Parmelee PA, Katz IR, Lawton MP (1989) Depression among institutionalized aged: assessment and prevalence estimation. J Gerontol 44: M22-29.

18. Paradela EM, Lourenço RA, Veras RP (2005) [Validation of geriatric depression scale in a general outpatient clinic]. Rev Saude Publica 39: 918-923.

19. American Psychiatric Association (APA) (1994). Diagnostic and statistical manual of mental disorders (DSM-IV). (4 ste dn). Washington, DC, American Psychiatric Associ $\neg$ ation.

20. Veras RP, Coutinho ES (1991) [Prevalence of depression and organic cerebral syndrome in the elderly population, Brazil]. Rev Saude Publica 25: 209-217.

21. Helene AF, Xavier GF (2003) [Building attention from memory]. Rev Bras Psiquiatr 25 Suppl 2: 12-20.

22. Squire LR, Kandel ER (2002) Memória: da mente às moléculas. Porto, Porto Editora.

23. Izquierdo I (2004) Questões sobre a memória. São Leopoldo, Unisinos.

24. Reys BN, Bezerra AB, Vilela AL, Keusen AL, Marinho V, et al. (2006) [Brief cognitive evaluation and diagnosis of dementia, depression, and psychosis in the elderly]. Rev Assoc Med Bras 52: 401-404.
25. Creutzberg M, Goncalves LHT, Sobottka EA (2008) Instituição de longa permanência para idosos: a imagem que permanece. Texto Contexto Enferm 17: 273-9.

26. Oliveira DA, Gomes L, Oliveira RF (2006) [Prevalence of depression among the elderly population who frequent community centers]. Rev Saude Publica 40: 734-736.

27. Yamamoto A, Diogo MJ (2002) [The elderly and asylums at the municipality of Campinas]. Rev Lat Am Enfermagem 10: 660-666.

28. Chaimowicz F, Greco DB (1999) [Dynamics of institutionalization of older adults in Belo Horizonte, Brazil]. Rev Saude Publica 33: 454-460.

29. Caldas CP (2003) [Aging with dependence: family needs and responsibilities]. Cad Saude Publica 19: 773-781.

30. Brasil. Ministério da Saúde. Secretaria de Gestão do Trabalho e Educação na Saúde (2008) Guia prático do cuidador. Brasília, Ministério da Saúde.

31. Rimpau W (2009) [Theory of cognition and natural philosophy in neurology. The principle of localization in the debate between Viktor von Weizsäcker, Kurt Goldstein, and Otfrid Foerster in 1930]. Nervenarzt 80: 970-974.

32. Bueno JLO (1997) O imaginário animal. Psicologia USP 8: 165-80.

33. Ricoeur P (2000) Teoria da interpretação. Lisboa, Edições 70.

34. Berger L (1995) Evitar os perigos. In: Berger L, Mailloux-Poirier D. Pessoas idosas. Lisboa, Lusodidacta 379-438.

35. Foucault M (2006) A hermenêutica do sujeito. (2 ste dn). São Paulo, Martins Fontes.

36. Soares E, Rossignoli PS (2014) Depression and cognitive decline: factors related to demographics and psycho pharmacotherapy on elderly in nursing homes. J Psychiatry 17: 2-9. 